\title{
LENGTH-WEIGHT RELATIONS FOR 14 FISH SPECIES OF LA PAZ BAY, BAJA CALIFORNIA SUR, MÉXICO
}

\author{
Víctor M. COTA-GÓMEZ*, Gustavo DE LA CRUZ-AGÜERO, \\ Francisco J. GARCÍA-RODRÍGUEZ, and José DE LA CRUZ-AGÜERO
}

\author{
Instituto Politécnico Nacional, Centro Interdisciplinario de Ciencias Marinas, Colección Ictiológica**, \\ La Paz, Baja California Sur, México
}

Cota-Gómez V.M., De La Cruz-Agüero G., García-Rodríguez F.J., De La Cruz-Agüero J. 2013. Length-weight relations for 14 fish species of La Paz Bay, Baja California Sur, México. Acta Ichthyol. Piscat. 43 (4): 297-298.

\begin{abstract}
The presently reported study provides length-weight relations of 14 fish species from mangrove swamps of La Paz Bay, Baja California Sur, México: Diapterus brevirostris (Sauvage, 1879); Eucinostomus currani Zahuranec, 1980; Eucinostomus dowii (Gill, 1863); Eucinostomus entomelas Zahuranec, 1980; Eucinostomus gracilis (Gill, 1862); Ctenogobius sagittula (Günther, 1862); Haemulopsis nitidus (Steindachner, 1869); Pomadasys bayanus Jordan et Evermann, 1898; Hyporhamphus naos Banford et Collette, 2001; Lutjanus argentiventris (Peters, 1869); Lutjanus novemfasciatus Gill, 1862; Mugil curema Valenciennes, 1836; Paralabrax maculatofasciatus (Steindachner, 1868); Sphoeroides annulatus (Jenyns, 1842). Fish were caught at 8 locations within July 2010-September 2011. Specimens were collected monthly using beach seines (mesh size $2.0 \mathrm{~cm}$ ), measured with a digital calliper, and weighed with a digital balance to determine the standard length and weight, respectively. Values of $b$ ranged from 2.21 to 3.45 .
\end{abstract}

Keywords: fish, length-weight relations, LWR, regression models, Mexican Pacific

Length-weight $(\mathrm{L}-\mathrm{W})$ relations of fish are important in fisheries research, partly because they allow the conversion of growth-in-length to growth-in-weight equations, and are used in determining stock structure and estimating fish condition (Mendes et al. 2004, Froese 2006, Ismen et al. 2009). In the presently reported study, L-W relations were estimated for 14 fish species collected in mangrove zones of La Paz Bay, BCS (Baja California Sur), Mexico (the largest body of water along the coast of Gulf of California).

Samples were collected from eight mangrove swamps of La Paz Bay, Baja California Sur, Mexico located within $24^{\circ} 06^{\prime}-24^{\circ} 48^{\prime} \mathrm{N}$ and $110^{\circ} 15^{\prime}-110^{\circ} 39^{\prime} \mathrm{W}$. Monthly sampling was conducted using beach seines $(25 \mathrm{~m}$ long and $1.5 \mathrm{~m}$ high; $2.0 \mathrm{~cm}$ mesh size) from July 2010 to September 2011. The fish were caught during high tide in the daytime and immediately euthanized, stored on ice, and transported to the laboratory where they were identified, measured (standard length, SL) with a digital calliper ( $\pm 0.1 \mathrm{~mm}$ precision), and weighed with an electronic scale $( \pm 0.01 \mathrm{~g}$ precision). All specimens were preserved in ethanol (after fixing in formalin) and catalogued in the ichthyology collection, CICIMAR-CI of the Centro Interdisciplinario de Ciencias Marinas at La Paz, BCS,
Mexico. The $\mathrm{L}-\mathrm{W}$ was described by the following regression equation (Le Cren 1951):

$$
W=a \mathrm{SL}^{b}
$$

where $W$ is the total weight [g], SL is the standard length [mm], $a$ is intercept, and $b$ is the slope. The parameters $a$ and $b$ were estimated by linear regression after a logarithmic transformation of weight and length data $(\log W=$ $\log a+b \log \mathrm{SL}$ ). Prior to regression analysis, log-log plots of the length-weight pairs were performed to identify outliers (Froese et al. 2011). Extreme outliers attributed to data error were excluded from the analyses.

In this study fourteen fish species, belonging to ten genera and eight families, were collected from the mangroves of La Paz Bay, Mexico: Gerreidae (including five species), Gobiidae, Haemulidae, Lutjanidae (each one including two species), Hemiramphidae, Mugilidae, Serranidae, and Tetraodontidae (each represented by one species): Diapterus brevirostris (Sauvage, 1879); Eucinostomus currani Zahuranec, 1980; Eucinostomus dowii (Gill, 1863); Eucinostomus entomelas Zahuranec, 1980; Eucinostomus gracilis (Gill, 1862); Ctenogobius sagittula (Günther, 1862); Haemulopsis nitidus (Steindachner, 1869); Pomadasys bayanus Jordan et Evermann, 1898; Hyporhamphus naos Banford et Collette, 2001; Lutjanus argentiventris (Peters, 1869);

\footnotetext{
${ }^{*}$ Correspondence: TPA Victor Manuel Cota Gómez, Instituto Politécnico Nacional, Centro Interdisciplinario de Ciencias Marinas, Colección Ictiológica, Avenida Instituto Politécnico Nacional s/n, Colonia Playa Palo de Santa Rita, La Paz, Baja California Sur, México 23096, phone: 52 (612) 1225344 ext. 82407 , fax: 52 (612) 1225322, e-mail: (VMCG)vcotag@ipn.com,vmcotag@hotmail.com; (GCA)gaguero@ipn.mx; (FJGR)fjgarciar@ipn.mx; (JDA) jcruz@ipn.mx.

${ }^{* *} \mathrm{http}: / /$ coleccion.cicimar.ipn.mx.
} 
Table 1

Length-weight relations (LWR) for 14 fish species caught in mangroves swamps of La Paz Bay, BCS, Mexico

\begin{tabular}{|c|c|c|c|c|c|c|c|c|c|c|c|c|c|}
\hline \multirow{2}{*}{ Species } & \multirow{2}{*}{ Family } & \multirow{2}{*}{ Stage } & \multirow{2}{*}{$n$} & \multicolumn{4}{|c|}{ LWR parameters } & \multicolumn{3}{|c|}{ Standard length $[\mathrm{mm}]$} & \multicolumn{3}{|c|}{ Weight $[\mathrm{g}]$} \\
\hline & & & & $a$ & $r^{2}$ & $b$ & $\mathrm{CI}$ & Min. & Max. & Mean & Min. & Max. & Mean \\
\hline Diapterus brevirostris & Gerreidae & $\mathrm{J}$ & 127 & 0.009 & 0.99 & 3.2 & $3.2-3.20$ & 2.2 & 24.0 & 7.6 & 0.50 & 214.9 & 8.5 \\
\hline Eucinostomus currani & Gerreidae & $\mathrm{J}$ & 149 & 0.011 & 0.98 & 3.0 & $3.0-3.01$ & 2.1 & 11.7 & 5.8 & 0.10 & 17.2 & 3.3 \\
\hline Eucinostomus dowii & Gerreidae & $\mathrm{J}$ & 200 & 0.007 & 0.98 & 3.2 & $3.2-3.23$ & 2.0 & 12.5 & 7.4 & 0.10 & 27.8 & 6.7 \\
\hline Eucinostomus entomelas & Gerreidae & $\mathrm{J}$ & 119 & 0.008 & 0.97 & 3.1 & $3.1-3.16$ & 4.6 & 15.3 & 9.5 & 1.10 & 45.3 & 12.2 \\
\hline Eucinostomus gracilis & Gerreidae & $\mathrm{J}$ & 22 & 0.032 & 0.98 & 2.4 & $2.4-2.54$ & 2.1 & 12.5 & 6.8 & 0.10 & 15.5 & 5.4 \\
\hline Ctenogobius sagittula & Gobiidae & $\mathrm{J}-\mathrm{A}$ & 77 & 0.028 & 0.99 & 2.2 & $2.2-2.41$ & 3.0 & 17.5 & 7.4 & 0.30 & 15.6 & 2.9 \\
\hline Haemulopsis nitidus & Haemulidae & $\mathrm{J}$ & 73 & 0.056 & 0.92 & 2.3 & $2.3-2.91$ & 6.6 & 8.7 & 9 & 4.6 & 8.8 & 7.3 \\
\hline Pomadasys bayanus & Haemulidae & $\mathrm{J}$ & 106 & 0.017 & 0.97 & 2.8 & $2.8-2.89$ & 5.6 & 13.8 & 9.2 & 2.3 & 33.7 & 11.3 \\
\hline Hyporhamphus naos & Hemiramphidae & A & 109 & 0.001 & 0.93 & 3.4 & $3.2-4.17$ & 19.0 & 29.0 & 25.0 & 17.2 & 74.5 & 44.8 \\
\hline Lutjanus argentiventris & Lutjanidae & $\mathrm{J}$ & 30 & 0.051 & 0.94 & 2.4 & $2.4-3.15$ & 4.7 & 10.7 & 7.7 & 1.4 & 17.1 & 8.2 \\
\hline Lutjanus novemfasciatus & Lutjanidae & $\mathrm{J}$ & 21 & 0.047 & 0.96 & 2.6 & $2.5-2.69$ & 2.9 & 23.0 & 9.3 & 0.40 & 183.6 & 24.2 \\
\hline Mugil curema & Mugilidae & $\mathrm{J}-\mathrm{A}$ & 213 & 0.016 & 0.99 & 2.8 & $2.8-2.85$ & 3.7 & 34.0 & 11.9 & 0.50 & 373.9 & 30.8 \\
\hline Paralabrax maculatofasciatus & Serranidae & $\mathrm{J}-\mathrm{A}$ & 193 & 0.014 & 0.99 & 2.9 & $2.9-3.0$ & 2.8 & 22.0 & 8.7 & 0.50 & 146.7 & 12.3 \\
\hline Sphoeroides annulatus & Tetraodontidae & $\mathrm{J}-\mathrm{A}$ & 33 & 0.009 & 0.99 & 3.3 & $3.3-3.35$ & 1.1 & 32.0 & 11.3 & 0.20 & 891.8 & 100.8 \\
\hline
\end{tabular}

$\mathrm{J}=$ juvenile, $\mathrm{A}=$ adult; $n=$ sample size; $a=$ intercept, $b=$ slope, $r^{2}=$ coefficient of determination, $\mathrm{CI}=95 \%$ confidence interval of $b$.

Lutjanus novemfasciatus Gill, 1862; Mugil curema Valenciennes, 1836; Paralabrax maculatofasciatus (Steindachner, 1868); Sphoeroides annulatus (Jenyns, 1842).

In total, 1472 fish individuals were collected and their length and weight were determined. All samples sizes $(n)$, minimum and maximum length and weight, parameters of $\mathrm{L}-\mathrm{W}$ relations ( $a$ and $b$ ), 95\% confidence interval (CI) of $b$, and the coefficient of determination $r^{2}$ by species are presented in Table 1. All relations were highly significant (for all $r^{2}>0.93, P<0.05$ ) and $b$ ranged from 2.216 to a maximum of 3.45. The low values of $b$ for several species (e.g., Ctenogobius sagittula: 2.216, Haemulopsis nitidus: 2.351 and Lutjanus argentiventris: 2.457$)$ in the presently reported study can be attributed in part to the limited observed length ranges of the specimens caught, because samples were composed of juveniles, given that the latter generally dominate in mangroves and the adults of the majority of these species are fast swimmers and could easily avoid beach seines. Thus, the $\mathrm{L}-\mathrm{W}$ relations presented here should not be used outside the indicated length ranges data. L-W relations for 12 out of the 14 species studied here are also available in FishBase (Froese and Pauly 2013) for other water bodies. In addition, for the majority of the studied species, included in FishBase, the confidence intervals of $b$ are not available, precluding a direct comparison, and for 12 of those, the $\mathrm{L}-\mathrm{W}$ relations refer to highly restricted sites (e.g., a small mangrove swamp; see González Acosta et al. 2004). For the Pacific silver stripe halfbeak, Hyporhamphus naos, and the spotted sand bass, Paralabrax maculatofasciatus, no $\mathrm{L}-\mathrm{W}$ relations are available in FishBase.

\section{ACKNOWLEDGEMENTS}

This research was supported by the Comisión Nacional para el Conocimiento y Uso de la Biodiversidad en México (Project: CONABIO GN030) and the Instituto Politécnico Nacional (SIP-20101038). We thank J.G. Chollet-Villalpando, F.J. Vergara-Solana, A. Payán-
Alcacio, J.A. Medina-Espinosa and A. Martínez-Guevara for their assistance in the fish samplings. We also thank support grants from the Sistema Nacional de Investigadores de México (JDA and FJGR) and EDI-IPN (GCA, FJGR, and JDA) and COFAA-IPN (VMCG, GCA, FJGR, and JDA).

\section{REFERENCES}

Froese R. 2006. Cube law, condition factor and weight-length relationships: history, meta-analysis and recommendations. Journal of Applied Ichthyology 22 (4): 241-253. DOI: 10.1111/j.1439-0426.2006.00805.x

Froese R., Pauly D. (eds.) 2013. FishBase. [version 10/2013] http://www.fishbase.org

Froese R., Tsikliras A.C., Stergiou K.I. 2011. Editorial note on weight-length relations of fishes. Acta Ichthyologica et Piscatoria 41 (4): 261-263. DOI: 10.3750/AIP2011.41.4.01

González Acosta A.F., De La Cruz Agüero G., De La Cruz Agüero J. 2004. Length-weight relationships of fish species caught in a mangrove swamp in the Gulf of California (Mexico). Journal of Applied Ichthyology 20 (2): 154-155. DOI: 10.1046/j.1439-0426.2003.00518.x

Ismen A., Yigin, C.C., Altinagac U., Ayaz A. 2009. Length-weight relationships for ten shark species from Saros Bay (North Aegean Sea). Journal of Applied Ichthyology 25 (Suppl. s1): 109-112. DOI: 10.1111/j.14390426.2009.01263.x

Le Cren E.D. 1951.The length-weight relationship and seasonal cycle in gonad weight and condition in the perch (Perca fluviatilis). Journal of Animal Ecology 20 (2): 201-219.

Mendes B., Fonseca P., Campos A. 2004. Weight-length relationships for 46 fish species of the Portuguese west coast. Journal of Applied Ichthyology 20 (5): 355-361. DOI: 10.1111/j.1439-0426.2004.00559.x

Received: 6 May 2013 Accepted: 14 October 2013 Published electronically: 31 December 2013 